\title{
Distribution and Diversity of Fiji's Terrestrial Herpetofauna: Implications for Forest Conservation ${ }^{1}$
}

\author{
Clare Morrison ${ }^{2}$
}

\begin{abstract}
In 2003 The Wildlife Conservation Society attempted to evaluate the conservation status of Fiji's natural forests including identifying a series of biological provinces (based on the distribution and endemism of a number of terrestrial taxa) in which some form of conservation area would need to be established or maintained. A combination of literature surveys, consultations with local researchers, and targeted field surveys was used to identify herpetological provinces within Fiji. With the exception of the iguanas (restricted to dry forest habitats), the frogs, and one of the skink species (restricted to wet forest habitats), the herpetofauna of Fiji is widespread in terms of both geography and habitat type and consequently there are no real distinct species assemblages or communities. Based on areas with the highest levels of herpetofauna species richness and endemism, forest reserves need to be established or maintained on Yadua Taba, Taveuni (particularly the northern and eastern sides), Ono-i-Lau, Ovalau, Gau, Rotuma, and the Monasavu area of Viti Levu to maximize conservation of herpetofauna diversity. Because there are gaps in the knowledge of geographic distributions of species resulting from incomplete surveys of several areas of the country, further targeted surveys are needed to completely evaluate the distribution of all herpetofauna species in Fiji.
\end{abstract}

FIJI's FORESTS AND wildlife are a unique blend of ancient continental groups and more recent arrivals from across the oeans that have diversified. The resulting forest ecosystems are still distinctly islandlike but are exceptionally species rich (Mitchell 1991, Ryan 2000). Many species and species groups occur only in Fiji, including an entire family of plants (Degeneriaceae), two unique iguanas, an endemic snake genus (Ogmodon), and a wealth of plants and invertebrates, many of

${ }^{1}$ This project was funded by The Wildlife Conservation Society as part of its "Conservation of Fiji's Forests and Wildlife: Building Conservation Landscapes into Forestry Operations and Forest Certification" project. Several of the field trips (Viwa, Viti Levu) were funded by the Pacific Biological Foundation. Manuscript accepted 7 October 2004.

${ }^{2}$ Institute of Applied Sciences, University of the South Pacific, Suva. Fiji. (e-mail: morrison_c@usp.ac.fj).

Pacific Science (2005), vol. 59, no. 4:481-489

(C) 2005 by University of Hawai'i Press

All rights reserved which are restricted to single islands, mountaintops, or watersheds (Ryan 2000).

Nearly $40 \%$ of Fiji's forests remain intact, and on some islands there are large expanses of forests extending from mountaintops $(>1,000 \mathrm{~m})$ down to the coast, thereby offering one of the few opportunities to conserve large blocks of rain-forest wilderness in the South Pacific. To date the conservation importance of Fiji forests has been largely overlooked by global and regional conservation analyses. In 2003 The Wildlife Conservation Society evaluated the conservation status of Fiji's natural forests as part of its "Conservation of Fiji's forests and wildlife: Building conservation landscapes into forestry operation and forestry certification" project (Farley et al. 2004). A herpetofauna survey was conducted as part of the overall Wildlife Conservation Society project to determine herpetological provinces that might be used to evaluate representation in Fiji's current forest reserve network.

The known terrestrial herpetofauna of Fiji consists of 30 species: 3 frogs, 2 iguanas, 3 snakes, 10 geckos, and 12 skinks. Forty per- 
cent $(12 / 30)$ of these species are endemic to Fiji, and a further $40 \%$ are considered native species. The remaining six species (20\%) are human-mediated colonizers (Morrison 2003). To date, work on the distribution and abundance of Fiji's herpetofauna has been fairly limited in scope. The work done by George Zug, Dick Watling, Paddy Ryan, Stanley Gorham, and other researchers has provided valuable information on the species; however, there remain many large gaps both in our knowledge and in areas of the country that are yet to be surveyed.

Consequently, the aims of this study were to (a) determine the geographic distribution of all species of terrestrial herpetofauna within Fiji; (b) identify preferred habitat types of all species; (c) identify herpetological assemblages and/or communities found in different habitats; and (d) identify areas of high species richness or endemism that should be included in Fiji's forest reserve network.

\section{MATERIALS AND METHODS}

Data were collected in three ways: (1) from an analysis of published and unpublished literature, (2) from consultations with other researchers familiar with these taxa in Fiji, and (3) from targeted field surveys. Key references used in data collation were Gibbons (1981), Gorham (1968, 1970), Morrison (2003), Ryan (2000), Shea (1995), and Zug (1991, 1995).

Targeted visual encounter surveys (VES) were carried out in Taveuni, Viti Levu, Gau, Viwa, and Vanua Levu between February and October 2003. Fixed-effort (16 person hours) diurnal and nocturnal surveys were carried out in a range of habitats on each of the islands. Data collected included presence/ absence of herpetofauna species, habitat, and microhabitat types.

Habitats on each island were assigned to one of nine vegetation classes based on Mueller-Dombois and Fosberg's (1998) description of the major vegetation types found in Fiji (and other Pacific Islands). Lowland rain forest is found in the wet zone of the high islands of Viti Levu and Vanua Levu and extends from near sea level to an altitude of $600 \mathrm{~m}$, with a mean annual rainfall of 2,000-3,000 mm. Upland rain forest occurs mostly in areas above $600 \mathrm{~m}$ in both the wet and dry zones, the latter toward the interior of the large islands. These areas receive a mean annual rainfall of 2,000-3,750 $\mathrm{mm}$. The cloud forests are mainly enshrouded in clouds and are restricted to mountaintops and ridges above $600 \mathrm{~m}$ near the coast and higher than $900 \mathrm{~m}$ inland with more than $9,000 \mathrm{~mm}$ of annual rainfall. Dry forests are only known to occur in parts of the dry zone of Viti Levu and Vanua Levu and some of the western islands. Rainfall is very low, with a mean annual range of $1,750-2,250 \mathrm{~mm}$. Talasiga vegetation is dry-zone vegetation found in fire-degraded environments and spreads from sea level to $1,000 \mathrm{~m}$. It receives a mean annual rainfall of 1,500-2,500 $\mathrm{mm}$. The freshwater wetland vegetation occurs only in the wet zone of Viti Levu in poorly drained alluvial sites along coastal flatland along the Rewa and Navua Rivers and is dominated by ferns, grasses, and sedges. Mangrove forests are associated with river estuaries and are found along the coastline. Moving landward, coastal stand vegetation changes from creepers and herbs to shrubs and trees. On Viti Levu such vegetation is only found on the northeastern coast, where human habitation is not as dense. Smallisland vegetation is a combination of coastal stand vegetation, mangrove forest, and talasiga vegetation. These islands receive a mean annual rainfall of approximately $2,000 \mathrm{~mm}$.

\section{RESULTS}

\section{Geographic Gaps in Knowledge}

There are many areas within Fiji that have not been surveyed adequately for reptiles and amphibians (Figure 1). On Viti Levu, the most obvious of these areas are Nakauvadra, Nakorotubu, Wainibuka, Serua, Malomalo, and the Koronayitu Range. The largest unsurveyed areas of Vanua Levu are Dreketi, Udu Point, Natewa Peninsula, Waisali, the Seatura Range, Saqani, and Vaturora. Surveys of most of these areas are unlikely to produce 


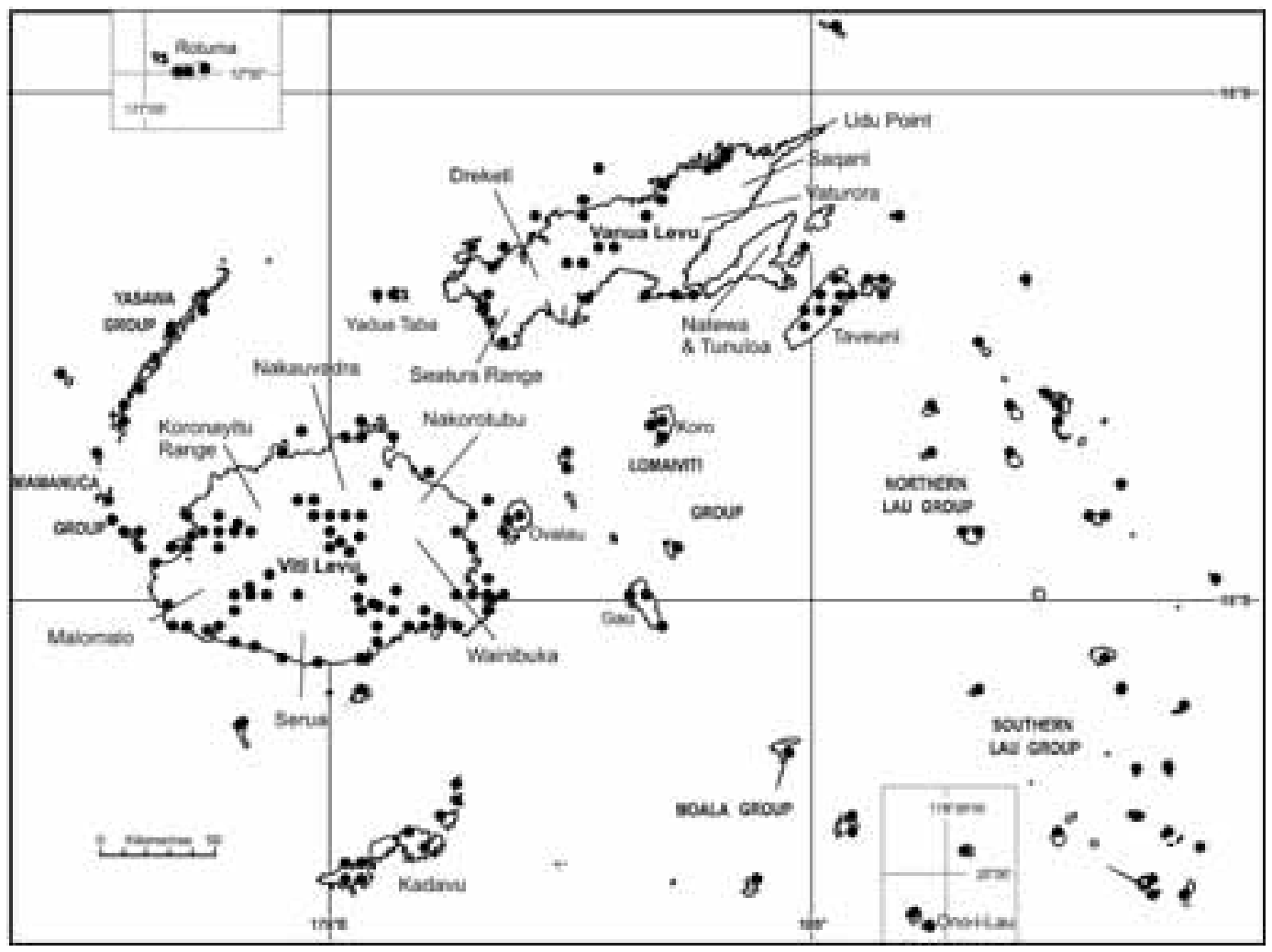

FIgURE 1. Areas in Fiji that have been surveyed for herpetofauna. Black dots represent species records (combination of vouchered specimens and sight records by reliable observers). Multiple dots in one area represent different species.

many species because they have been heavily disturbed by forest clearing. Areas worth surveying in the future are Natewa Peninsula, Waisali, and the Seatura Range on Vanua Levu and the Koronayitu Range, Nakorotubu, and Wainibuka on Viti Levu. The islands in the Lau Group have been surveyed, but most surveys were conducted before 1990 and usually with less than a day of field searching.

Geographic Distribution and Habitat Type for Known Terrestrial Fauna

Most species have broad geographic distributions and are found on several islands throughout Fiji (Tables 1 and 2). There are, however, several exceptions, including two species with very restricted distributions that are considered local endemics (restricted to single islands or island groups): Lepidodactylus gardineri and Leiolopisma alazon (discussed in more detail later in this article). Six other species also have a restricted documented distribution: Ogmodon vitianus occurs only in the interior of Viti Levu; Emoia campbelli is known only from the Monasavu area on Viti Levu; E. caeruleocauda has been recorded from only two sites on Viti Levu and one on Taveuni; E. mokosariniveikau has been confirmed from only two locations on Vanua Levu; and E. nigra and Platymantis vitianus have been extirpated from much of their original range, essentially limiting them to mongoose-free islands (Morrison 2003).

Many of the species are also found in more than one major habitat type (Table 1). The most common are Gebyra oceanica (six habi- 
TABLE 1

Detailed Geographic Distribution and Habitat Type for Known Terrestrial Herpetofauna in Fiji Based on Literature

\begin{tabular}{|c|c|c|c|}
\hline Species & Geographic Distribution $^{a}$ & Habitat Type ${ }^{b}$ & Distribution $^{c}$ \\
\hline Platymantis vitianus $^{* d}$ & $\begin{array}{l}\mathrm{VL}^{e}, \mathrm{VAL}, \mathrm{TA}, \mathrm{OV}, \mathrm{KO}, \mathrm{GA}, \\
\text { KA, VI }\end{array}$ & LRF, CSV, AGR & WIDE \\
\hline P. vitiensis ${ }^{* d}$ & VL, VAL, TA, OV & LRF, HRF, AGR & WIDE \\
\hline Candoia bibronid & VL, TA, OV, KA, VI & DF, LRF, CSV & WIDE \\
\hline Ogmodon vitianus* & $\mathrm{VL}$ & LRF, AGR & REST (geog.) \\
\hline Brachylophus fasciatus & $\begin{array}{l}\text { VL, VAL, OV, KO, MM, } \\
\text { NLA, SLA }\end{array}$ & CSV, DF, SIV & WIDE \\
\hline B. vitiensis* & YAT, YAS, Macuata Is. & DF & REST (geog.) \\
\hline Gebyra mutilata & VL, OV, ROT & URB, AGR & WIDE \\
\hline G. oceanicad & Found throughout & CSV, MAN, LRF, DF, SIV, URB & WIDE \\
\hline G. vorax & VL, VAL, TA, OV, GA, KO & LRF & WIDE \\
\hline Hemidactylus frenatus & VL, VAL, OV, MM & URB & WIDE \\
\hline H. garnotti & $\mathrm{VL}, \mathrm{TA}$ & URB, AGR & WIDE \\
\hline Hemiphyllodactylus typus ${ }^{d}$ & VL, VAL & URB, AGR, LRF & WIDE \\
\hline Lepidodactylus manni* & VL, OVA, KA & LRF, HRF, DF & WIDE \\
\hline L. lugubris & Found throughout & URB, AGR, CSV, SIV, LRF & WIDE \\
\hline L. gardineri* & ROT & LRF, CSV & WIDE \\
\hline Nactus pelagicus ${ }^{d}$ & Found throughout & CSV, AGR, SIV, LRF & WIDE \\
\hline Cryptoblepharus eximius*d & $\begin{array}{l}\text { VL, VAL, KO, OV, YAT, TA, } \\
\text { MO, KA, NLA, SLA }\end{array}$ & $\mathrm{CSV}, \mathrm{SIV}$ & WIDE \\
\hline Leiolopisma alazon* & Ono-I-Lau & SIV & END \\
\hline Lipinia noctuad & Found throughout & CSV, LRF, SIV & WIDE \\
\hline Emoia cyanura & Found throughout & LRF, CSV, AGR, SIV & WIDE \\
\hline E. impar & Found throughout & LRF, CSV, AGR, SIV & WIDE \\
\hline E. caeruleocauda & VL, TA & AGR, DF, LRF & WIDE \\
\hline E. campbelli* & $\mathrm{VL}$ & $\mathrm{HRF}$ & END (Monasav \\
\hline E. concolor ${ }^{* d}$ & Found throughout & LRF, HRF, AGR, SIV, DF & WIDE \\
\hline E. parkeri ${ }^{\star d}$ & VL, OV, KA, TA & LRF, DF & WIDE \\
\hline E. nigra & $\mathrm{VL}^{e}, \mathrm{VAL}^{e}, \mathrm{TA}, \mathrm{OV}, \mathrm{KO}, \mathrm{ROT}$ & AGR, LRF, SIV & WIDE $f$ \\
\hline E. trossula & $\begin{array}{l}\text { VL, VAL, KA, YAT, TA, OV, } \\
\text { GA, MO, YAS, NLA, SLA }\end{array}$ & AGR, LRF, SIV, DF & WIDE \\
\hline E. mokosarineveikau ${ }^{\star d}$ & VAL, VL & LRF & REST (geog.) \\
\hline
\end{tabular}

*, Endemic to Fiji.

${ }^{a}$ VL, Viti Levu; VAL, Vanua Levu; TA, Taveuni; KA, Kadavu; OV, Ovalau; KO, Koro; GA, Gau; YAS, Yasawas; YAT, Yadua Taba; MO, Moala Group; MM, Mamanuca Group; NLA, northern Lau Group; SLA, southern Lau Group; VI, Viwa; ROT, Rotuma.

${ }^{b}$ LRF, Lowland rain forest; HRF, highland rain forest; DF, dry forest; MAN, mangrove; CSV, coastal stand vegetation; SIV small-island vegetation; URB, urban (buildings, human-made structures); AGR, agriculture, including gardens.

${ }^{c}$ WIDE, Wide distribution based on geography and habitat type; REST, restricted to particular habitat type or geographic location; END, endemic to a particular habitat type and geographic location.

${ }^{d}$ Species for which additional data were collected during recent field studies and not found in key references.

${ }^{e}$ Now believed to be extinct on these islands.

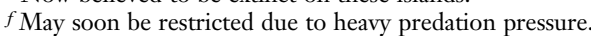

tats), Emoia concolor (five), and Nactus pelagicus, E. cyanura, E. impar, and E. trossula (four each). Five species are restricted to a particular habitat: E. mokosariniveikau and G. vorax in lowland rain forest, E. campbelli in upland rain forest, Brachylophus vitiensis in dry forest, and Leiolopisma alazon in small-island vegetation. The rest of the species occur in two to three different habitats throughout the country.

\section{Species within Each Major Habitat Type}

Lowland rain forest, dry forest, and highland rain forest are the three most important habitat types in terms of herpetofauna species richness and endemicity (Table 3). Lowland rain forest supports 18 species, three of which are endemic to the habitat, including one local endemic (Lepidodactylus gardineri) in Rotuma. Dry forest supports nine species, in- 
TABLE 2

Summary of Targeted Field Surveys between February and November 2003

\begin{tabular}{|c|c|c|c|}
\hline Island & Site Name & Habitat Type(s) ${ }^{a}$ & Species \\
\hline \multirow[t]{6}{*}{ Viti Levu } & Wailotua & LRF & E. concolor, G. oceanica, P. vitiensis \\
\hline & South Sovi & LRF & $\begin{array}{l}\text { C. bibroni, C. eximius, E. concolor, E. cyanura, G. oceanica, } \\
\text { N. pelagicus, P. vitiensis }\end{array}$ \\
\hline & Central Sovi & LRF & $\begin{array}{l}\text { C. bibroni, C. eximius, E. concolor, E. cyanura, G. oceanica, } \\
\text { N. pelagicus, P. vitiensis }\end{array}$ \\
\hline & Vatia & DF & $\begin{array}{l}\text { E. concolor, E. cyanura, E. impar, G. oceanica, H. typus, } L \text {. } \\
\text { lugubris }\end{array}$ \\
\hline & Sigatoka Valley & LRF & E. concolor, E. cyanura, G. oceanica \\
\hline & Wabu & HRF & E. concolor, P. vitiensis \\
\hline \multirow[t]{4}{*}{ Vanua Levu } & Dogotuki & LRF, MAN & $\begin{array}{l}\text { C. bibroni, C. eximius, E. concolor, E. cyanura, G. oceanica, } \\
\text { L. noctua, N. pelagicus, P. vitiensis }\end{array}$ \\
\hline & Mali Island & TAL & C. eximius, E. cyanura, G. oceanica \\
\hline & Waisali & LRF & $\begin{array}{l}\text { E. concolor, E. cyanura, E. mokosariniveikau, } N \text {. pelagicus, } \\
\text { P. vitianus, P. vitiensis }\end{array}$ \\
\hline & Waitabu & $\mathrm{DF}$ & E. concolor, E. cyanura, G. oceanica, H. typus, L. noctua \\
\hline Viwa & Viwa Village & LRF, MAN, AGR & $\begin{array}{l}\text { B. fasciatus, C. bibroni, E. concolor, E. cyanura, E. impar, } \\
\text { G. oceanica, H. frenatus, L. lugubris, L. noctua, N. } \\
\text { pelagicus, P. vitianus }\end{array}$ \\
\hline \multirow{4}{*}{ Taveuni } & Lake Tagimaucia & $\mathrm{HRF}$ & C. bibroni, E. concolor, P. vitianus \\
\hline & Somosomo & LRF, AGR & $\begin{array}{l}\text { C. bibroni, E. concolor, E. cyanura, E. nigra, G. oceanica, } \\
\text { H. frenatus, L. lugubris, N. pelagicus, P. vitianus, } P \text {. } \\
\text { vitiensis }\end{array}$ \\
\hline & Waitavala & LRF & $\begin{array}{l}\text { C. bibroni, E. concolor, E. cyanura, E. impar, E. nigra, G. } \\
\text { oceanica }\end{array}$ \\
\hline & Lavena & LRF & $\begin{array}{l}\text { E. concolor, E. cyanura, E. nigra, E. trossula, G. oceanica, } \\
\text { N. pelagicus, P. vitianus }\end{array}$ \\
\hline \multirow[t]{3}{*}{ Gau } & Nawaikama & LRF & B. fasciatus, C. bibroni, E. concolor, N. pelagicus, P. vitianus \\
\hline & Nukuloa & LRF & C. bibroni, $N$. pelagicus, $P$. vitianus \\
\hline & Lovu & LRF & C. bibroni, $N$. pelagicus, $P$. vitianus \\
\hline Eciwa & Eciwa & SIV & C. eximius, E. concolor, E. cyanura \\
\hline Matagi & Matagi & CSV & C. eximius, E. cyanura, E. impar \\
\hline
\end{tabular}

${ }^{a}$ LRF, Lowland rain forest; HRF, highland rain forest; DF, dry forest; MAN, mangrove; CSV, coastal stand vegetation; SIV, small-island vegetation; TAL, Talasiga; AGR, agriculture, including gardens.

cluding one endemic (the endangered Brachylophus vitiensis) that can almost be referred to as a local endemic (Yadua Taba is the stronghold). Highland rain forest supports five species, one of which is endemic to the habitat, Emoia campbelli. Coastal stand vegetation, agricultural areas, and small-island vegetation each support 10 species, but there are no species endemic to these habitats and all species found in these areas are also common in other habitats. The majority of the species occurring in urban areas are human-mediated colonizers rarely found in other habitats.

Because dry forest is the most endangered vegetation habitat type in Fiji (Laurie et al.
1987, Olson et al. 2002), its role in supporting reptile species has become more important and/or crucial. The dry forest on Yadua Taba not only supports the largest population of Fijian crested iguanas (Brachylophus vitiensis) but is also an important habitat for Emoia trossula and other species occurring in (but not restricted to) dry forest that are severely affected by mongoose predation.

\section{Species Assemblages}

As previously mentioned, there are very few species restricted to a single habitat type or single location. Consequently, there are no 
TABLE 3

Species within Each Major Habitat Type

\begin{tabular}{|c|c|c|}
\hline Habitat Type & Species Present & Endemic Species ${ }^{a}$ \\
\hline Lowland rain forest & $\begin{array}{l}\text { P. vitianus, } \text { P. vitiensis, C. bibroni, O. vitianus, G. oceanica, } \\
\text { G. vorax, L. gardineri }{ }^{*} \text {, L. lugubris, L. manni, E. } \\
\text { concolor, Hemiphyllodactylus typus, E. nigra, E. trossula, } \\
\text { E. cyanura, E. impar, E. parkeri, E. mokosarineveikau, } \\
\text { N. pelagicus }\end{array}$ & $\begin{array}{l}\text { L. gardineri* (ROT), } \\
\text { E. mokosarineveikau, } \\
\text { G. vorax }\end{array}$ \\
\hline Highland rain forest & P. vitianus, P. vitiensis, L. manni, E. concolor, E. campbelli* & E. campbelli* $(\mathrm{MON})$ \\
\hline Cloud forest & P. vitiensis & \\
\hline Dry forest & $\begin{array}{l}\text { B. fasciatus, B. vitiensis*, C. bibroni, G. oceanica, E. } \\
\text { parkeri, E. caeruleocauda, E. concolor, E. cyanura, E. } \\
\text { trossula, L. manni, Hemiphyllodactylus typus }\end{array}$ & $\begin{array}{l}\text { B. vitiensis* (YAT, } \\
\text { YAS, Macuata Is.) }\end{array}$ \\
\hline Mangroves & G. oceanica & \\
\hline Coastal stand & $\begin{array}{l}\text { P. vitianus, B. fasciatus, C. bibroni, G. oceanica, } L . \\
\text { gardineri, L. lugubris, C. eximius, E. cyanura, E. impar, } \\
\text { Lipinia noctua }\end{array}$ & \\
\hline Urban & $\begin{array}{l}\text { G. mutilata, G. oceanica, L. lugubris, H. frenatus, } H \text {. } \\
\text { garnotti, Hemiphyllodactylus typus }\end{array}$ & H. frenatus \\
\hline Agricultural & $\begin{array}{l}\text { G. oceanica, L. lugubris, H. garnotti, E. concolor, } \\
\text { Hemiphyllodactylus typus, E. caeruleocauda, E. impar, E. } \\
\text { cyanura, E. trossula, E. nigra }\end{array}$ & \\
\hline Small-island vegetation & $\begin{array}{l}\text { B. fasciatus, G. oceanica, L. lugubris, N. pelagicus, } \\
\text { Leiolopisma alazon*, Lipinia noctua, E. eximius, E. } \\
\text { concolor, E. cyanura, E. impar }\end{array}$ & L. alazon* $(\mathrm{ONO})$ \\
\hline
\end{tabular}

*, Local endemics (restricted to a particular habitat type in a specific geographic location). Group).

${ }^{a}$ ROT, Rotuma; MON, Monasavu (central Viti Levu); YAT, Yadua Taba; YAS, Yasawas; ONO, Ono-i-Lau (southern Lau

clearly defined species assemblages for the different habitat types.

The only split in habitat type that can be loosely made using reptile and amphibian species in Fiji is that between wet and dry forests. Both general habitat types have a number of species (nine in total) in common; however, the two iguana species are restricted to dry forest and the two frog species and Emoia campbelli are restricted to wet forest habitats. It is important to note, however, that these are not always reliable indicators because not all dry forests have iguanas and not all wet forests have frogs and/or $E$. campbelli.

\section{Local Endemics}

There are two locally endemic reptile species in Fiji: the Rotuman gecko (Lepidodactylus gardineri) and the Lauan skink (Leiolopisma alazon), restricted to Rotuma and Ono-i-Lau in the southern Lau Group, respectively. The relatively isolated location of Rotuma suggests that $L$. gardineri is unlikely to be found elsewhere and is almost definitely a true local endemic. Because there are several islands in relatively close proximity to Ono-iLau we cannot rule out the possibility that $L$. alazon occurs on other islands in the region. Consequently, a thorough survey of the Lau Group (especially the southern islands in the group) should be conducted to confirm the distribution of this species (and others) in the region.

Ogmodon vitianus is monotypic and closely related to the Toxicocalamus group (New Guinea forest snakes [Keogh et al. 1998]). To date it is considered restricted to the $\mathrm{Na}$ vua and Rewa watersheds of southeastern Viti Levu. It appears to be a montane valley species that prefers moist deep soil of forests or recently forested areas ( $\mathrm{Zug}$ and Ineich 1993). Due to its fossorial nature, records of 
TABLE 4

Declining Herpetofauna Species in Fiji and Probable Causes of Declines

\begin{tabular}{|c|c|c|c|}
\hline Species & Original Range $^{a}$ & Current Range ${ }^{a}$ & Causal Agent ${ }^{b}$ \\
\hline Batrachylophus fasciatus & $\begin{array}{l}\text { Found throughout, } \\
\text { especially eastern side } \\
\text { of Fiji }\end{array}$ & $\begin{array}{l}\text { Still found throughout but } \\
\text { in much lower numbers }\end{array}$ & $\begin{array}{l}\text { Habitat destruction and } \\
\text { fragmentation }(\mathrm{P}), \\
\text { predation by mongoose and } \\
\text { rats }(\mathrm{S})\end{array}$ \\
\hline Batrachylophus vitiensis* & $\begin{array}{l}\text { YAT, YAS, Monuriki Is., } \\
\text { Monu Is., Macuata Is. }\end{array}$ & YAT, Macuata Is. & $\begin{array}{l}\text { Habitat destruction }(\mathrm{P}) \text {, } \\
\text { predation by rats }(\mathrm{S})\end{array}$ \\
\hline Emoia nigra & $\begin{array}{l}\text { VL, VAL, TA, GA, OV, } \\
\text { KO }\end{array}$ & TA, GA, KO & $\begin{array}{l}\text { Predation by mongoose and } \\
\text { cats }(\mathrm{P})\end{array}$ \\
\hline Emoia parkeri* & VL, KA, OV, KO, TA & $\begin{array}{l}\text { Highland VL, KA, OV, } \\
\text { KO, TA }\end{array}$ & $\begin{array}{l}\text { Habitat loss and fragmentation } \\
(\mathrm{P}) \text {, predation by mongoose } \\
\text { and rats }(\mathrm{S})\end{array}$ \\
\hline Emoia trossula & $\begin{array}{l}\text { VL, TA, YAT, OV, KO, } \\
\text { GA, KA, NLA, SLA }\end{array}$ & $\begin{array}{l}\text { TA, YAT, KO, KA, NLA, } \\
\text { SLA }\end{array}$ & $\begin{array}{l}\text { Predation by mongoose, rats, } \\
\text { and cats }(\mathrm{P})\end{array}$ \\
\hline Lepidodactylus manni* & $\mathrm{VL}, \mathrm{VAL}, \mathrm{OV}, \mathrm{KA}$ & Eastern VL, VAL, OV, KA & $\begin{array}{l}\text { Habitat destruction and } \\
\text { fragmentation }(\mathrm{P})\end{array}$ \\
\hline Platymantis vitianus* & $\begin{array}{l}\text { VL, VAL, TA, OV, GA, } \\
\text { VI }\end{array}$ & $\begin{array}{l}\text { VAL (one population), TA, } \\
\text { OV, GA, VI }\end{array}$ & $\begin{array}{l}\text { Predation by mongoose }(\mathrm{P}), \\
\text { rats and cats }(\mathrm{S}), \\
\text { competition from cane } \\
\text { toads }(\mathrm{S})\end{array}$ \\
\hline
\end{tabular}

* Endemic species.

${ }^{a}$ VL, Viti Levu; VAL, Vanua Levu; TA, Taveuni; KA, Kadavu; OV, Ovalau; KO, Koro; GA, Gau; YAS, Yasawas; YAT, Yadua Taba; NLA, northern Lau Group; SLA, southern Lau Group; VI, Viwa.

${ }^{b} \mathrm{P}$, Primary threat; S, secondary threat.

its distribution are few and consequently its distribution may be more widespread than currently believed.

\section{Species Declines}

Several species that were once fairly widespread throughout Fiji have been extirpated from much of their original range due to a number of causes including habitat destruction and predation (Table 4). The most severely impacted of these species are Brachylophus vitiensis (recent surveys have recorded this species from only two islands), Platymantis vitianus (with the exception of one population on Vanua Levu it is believed extirpated from mainland Fiji), Emoia trossula, and $E$. nigra (now occurs only on mongoose-free islands).

\section{DISCUSSION}

\section{Geographic Gaps in Knowledge}

Because of logistical restraints and restrictions due to the location of previous surveys, there are several large areas in Fiji that have been inadequately surveyed or not surveyed at all for herpetofauna. Although some are fairly considerable in size, surveys of most of these areas are unlikely to produce many species because they have been heavily disturbed by forest clearing. Areas worth surveying in the future are the Natewa Peninsula, Waisali, and the Seatura Range on Vanua Levu; the Koronayitu Range, Nakorotubu, and Wainibuka areas on Viti Levu; and the northern and southern Lau Groups.

\section{Areas with Highest Species Richness and/or Diversity}

The forest types that support the highest herpetofauna species richness and diversity are lowland rain forest, highland rain forest, and dry forest. Consequently, these habitats are the most important to the preservation of herpetofauna in Fiji. Lowland rain forest is found throughout the Fiji Islands; however, the lowland rain forest areas with the greatest herpetofauna species richness and diversity 
are found mainly in Taveuni, Gau, Ovalau, and the southeastern corner of Viti Levu. The highland rain forest has a more restricted distribution than lowland rain forest, with the best sites for herpetofauna conservation being Monasavu (Viti Levu), Taveuni, and Gau. Dry forest is by far the most restricted of the three important habitats and, as such, all dry forest areas should be conserved including those on Yadua Taba, Vatia Peninsula (Viti Levu), and Waitabu (Vanua Levu).

\section{Species Declines}

Many of the species of reptiles and amphibians in Fiji are now missing from much of their original ranges. These local extinctions have been attributed to several factors including habitat destruction, modification, and pollution and the introduction of predators (Watling and Zug 1998).

Extensive deforestation has accompanied the expansion of modern agriculture in Fiji and has subsequently had a severe detrimental impact on ecological communities. Many of the native and endemic herpetofauna species are adapted to a forest environment and appear incapable of adapting to humanmodified habitats, resulting in severe population declines and in some cases extirpation from deforested areas (Pernetta and Watling 1978, Watling and Zug 1998). The majority of the deforestation has occurred in lowland rain forest, the habitat type with the most herpetofauna species diversity in Fiji. Fortunately, there are several large blocks of intact lowland rain forest in the interior of Viti Levu and Vanua Levu, although these blocks are yet to be officially protected from deforestation or logging. Fijian dry forest is one of the most endangered forest types in the $\mathrm{Pa}$ cific and is the habitat of the Fiji crested iguana (Brachylophus vitiensis). Currently there are less than five intact patches of dry forest remaining in Fiji; the remainder have been cleared for agriculture or invaded by alien plant and animal species. Every effort is being made to conserve these few remaining dry forests.

Habitat destruction aside, predation by mongoose is a devastating factor affecting species abundance and distribution (Pernetta and Watling 1978, Case et al. 1992, Watling and Zug 1998). Mongooses are believed responsible for the extirpation of many of the terrestrial herpetofauna species on the mainland islands of Viti Levu and Vanua Levu (Gorman 1975, 1977, Pernetta and Watling 1978, Ryan 2000, Morrison 2003). This is particularly apparent in the case of the Fiji ground frog (Platymantis vitianus) and several of the larger skink species (e.g., Emoia nigra and E. trossula, which are no longer known to coexist with mongoose on Viti Levu and Vanua Levu but survive quite well on mongoose-free islands). Arboreal and semiarboreal herpetofauna species appear less affected but still have demonstrated severe declines in abundance and have become locally extinct in some areas of Viti Levu and Vanua Levu. The removal of mongoose from areas of the mainland is not feasible, highlighting the importance of the "mongoosefree islands" as reserves for amphibian and reptile species (e.g., Taveuni, Gau, Viwa, Yadua Taba). Other predators, namely cats and rats, also affect terrestrial species but may be more damaging to arboreal species, including iguanas (Gibbons and Watkins 1982). Predators may not wipe out all individuals in a population but, combined with habitat destruction, may reduce herpetofauna densities to a level too low for populations to survive, thereby resulting in local extinctions.

\section{ACKNOWLEDGMENTS}

I thank D. Watling, G. Zug, P. Harlow, and A. Naikatini for discussions and permitting use of their unpublished species distribution field data. N. Thomas, I. Rounds, A. Naikatini, and M. Tokota'a provided valuable assistance during field surveys.

\section{Literature Cited}

Case, T. J., D. T. Bolger, and A. D. Richman. 1992. Reptilian extinctions: The last ten thousand years. Pages 91-125 in P. L. Fiedler and S. K. Jain, eds. Conservation biology. Chapman and Hall, New York.

Farley, L. S., A. Patrick, and D. M. Olson. 
2004. Conservation of Fiji's forests and wildlife: Building conservation landscapes into forestry operations and forest certification. The Wildlife Conservation Society-South Pacific, Suva, Fiji.

Gibbons, J. R. H. 1981. The biogeography of Brachylophus (Iguanidae) including the description of a new species, B. vitiensis, from Fiji. J. Herpetol. 15 (3): 255-273.

Gibbons, J. R. H., and I. F. Watkins. 1982. Behaviour, ecology, and conservation of South Pacific banded iguanas, Brachylophus, including a newly discovered species. Pages 418-441 in G. M. Berghardt and A. S. Rand, eds. Iguanas of the world, their behaviour, ecology and conservation. Noyes, Park Ridge, New Jersey.

Gorham, S. W. 1968. Fiji's frogs; life history and data from field work. Zool. Beitr. 14:427-446.

- 1970. The rare Fiji snake Ogmodon vitianus Peters. Fiji Agric. J. 32:49-51.

Gorman, M. L. 1975. The diet of feral Herpestes auropunctatus (Carnivora: Viverridae) in the Fijian Islands. J. Zool. (Lond.) 175:275-278.

. 1977. The mongoose. University of Aberdeen, United Kingdom.

Keogh, J. S., R. Shine, and S. Donnellan. 1998. Phylogenetic relationships of terrestrial Australo-Papuan elapid snakes (Subfamily Hydrophiinae) based on cytochrome b and $16 \mathrm{~S}$ rRNA sequences. Mol. Phylogenet. Evol. 10 (1): 67-81.

Laurie, W. A., H. Uryu, and D. Watling. 1987. A faunal survey of Yaduataba Island reserve with particular reference to the crested iguana (Batrachylophus vitiensis Gibbons 1981). Domodomo 5 (1-2): 16-28.

Mitchell, A. 1991. A fragile paradise: Nature and man in the Pacific. Collins, London.
Morrison, C. 2003. A field guide to the herpetofauna of Fiji. Institute of Applied Sciences, University of the South Pacific, Suva, Fiji.

Mueller-Dombois, D., and F. R. Fosberg. 1998. Vegetation of the tropical Pacific islands. Springer-Verlag, New York.

Olson, D. M., M. V. Tuiwawa, J. Niukula, P. Biciloa, G. Keppel, A. Naikatini, B. Thaman, and L. Vakausausa. 2002. Conservation of Fijian dry forest and Fijian crested iguanas on Yadua Taba Island. The Wildlife Conservation Society-South Pacific, Suva, Fiji.

Pernetta, J. C., and D. Watling. 1978. The introduced and native terrestrial vertebrates of Fiji. Pacific Science 32:223244.

Ryan, P. A. 2000. Fiji's natural heritage. Exisle Publishing, Auckland, New Zealand.

Shea, G. M. 1995. A small collection of skinks and geckos from the northwestern islands of Fiji (Yasawa and Mamanuca Groups). Pacific Science 49:126-133.

Watling, D., and G. Zug. 1998. Annotated list and conservation status of Fijian terrestrial reptiles and amphibians. Fiji Biodiversity Strategy and Action Plan, Technical Group 2: Terrestrial vertebrates and invertebrates. Available from Department of Environment, Government of Fiji, Suva.

Zug, G. R. 1991. The lizards of Fiji: Natural history and systematics. Bishop Mus. Bull. Zool. 2:1-136.

1995. A new skink (Emoia: Lacertilia: Reptilia) from the forest of Fiji. Proc. Biol. Soc. Wash. 108 (3): 395-400.

Zug, G. R., and I. Ineich. 1993. Review of the biology and morphology of the Fijian Bola, Ogmodon vitianus (Elapidae). Snake 25:9-20. 